\title{
KIRJOITUS
}

ULLA SIIRTO

\section{People on the Move - tutkijan reflektio}

\nterdiac on Itä- ja Keski-Euroopan kristillistä sosiaalityötä ja diakoniaa
kehittävä järjestö, joka tarjoaa pidempiä ja lyhyempiä koulutuksia kirkkojen ja kristillisten järjestöjen työntekijöille ja vapaaehtoisille erityisesti itäisessä Euroopassa. Suomella on ollut pitkään vahvat suhteet Interdiaciin erityisesti Diakonissalaitoksen ja Diakonia-ammattikorkeakoulun kautta. Ne ovat olleet perustamassa Interdiacia ja Diak on tukenut koulutuksellista puolta eri tavoin antamalla opettajaresursseja Interdiacin käyttöön.

Interdiacin 10-vuotisjuhlissa vuonna 2018 syntyi ajatus kolmen tutkimusprosessin koordinoinnista. Yksi niistä liittyi diakoniseen seurakuntaan (Addy, 2020), toinen muuttoliikkeeseen (Addy \& Prosvirnina, 2020a) ja kolmas marginaaleissa eläviin nuoriin (Addy \& Prosvirnina, 2020b). Minua pyydettiin teemakoordinaattoriksi viimeksi mainittuun tutkimusprosessiin. Tutkimushankkeen "People on the Move" koordinointi tapahtui Interdiacin vastuuopettajan Oksana Prosvirninan johdolla. Hän otti yhteyttä Interdiacin kumppaneihin ja tarjosi mahdollisuutta osallistua tutkimushankkeeseen. Samalla tavoin toimittiin myös kahden muun tutkimushankkeen kohdalla. Lopulta kuuden maan edustajat lähtivät mukaan "People on the Move" -tutkimushankkeeseen: Armenia, Puola, Serbia, Třekki, Ukraina ja Unkari. Unkarista, Tsekistä ja Puolasta oli mukana paikallinen luterilainen kirkko, muista uskontoperustainen järjestö ( $\mathrm{FBO}=$ faith based organisation).

Tutkimusprosessin oli tarkoitus käynnistyä keväällä 2019, mutta osallisten rekrytointi vei odotettua pidemmän ajan ja pääsimme aloittamaan vasta 
saman vuoden kesällä. Oksana Prosvirnina käytti tähän vaiheeseen paljon aikaa ja energiaa. Sillä aikaa itse valmistelin haastattelukysymyksiä ensin niille, jotka muuttavat, sittemmin niille, jotka työskentelevät heidän parissaan. Haastatellut muuttajat edustivat sekä sisäisiä pakkomuuttajia että maasta toiseen muuttavia pakolaisia ja työn, parisuhteen tai opiskelun takia muuttavia. Lisäksi valmistelin ohjeet paikallisille yhdyshenkilöille, jotka toimivat tutkimushankkeessa kanssatutkijoina (engl. practitioner researcher). Tutkimus valmistui syksyllä 2020 .

Tutkimuksen perusorientaationa oli osallistava tutkimus, jonka tarkoituksena on saada tutkimuksen keskiössä olevat ihmiset mukaan tutkimuksen tekemiseen (ks. lisää Sarajärvi \& Tuomi, 2017). Kaikilta osin tämä ei lähtökohdissaan onnistunut aikataulusyistä - rahoituksen raamit määrittelivät aikataulun. Tutkimusprosessien ohjausryhmä oli kuitenkin omaksunut ajatuksen osallistavasta tutkimuksesta ja oli lisäksi märitellyt tutkimuksen vaiheittaiseksi. Tutkimus sisälsi ensin maaraporttien kirjoittamisen, sitten muuttoliikkeessä olevien ihmisten haastatteluvaiheen sekä ammattilaisten haastatteluvaiheen.

Ensimmäisessä vaiheessa kanssatutkijat koostivat maaraportin maansa maahanmuuttotilanteeseen liittyen. Nämä maaraportit toimivat pohjana koko tutkimukselle ja antoivat myös sisältöä joidenkin haastattelukysymysten muotoilulle. Toisessa vaiheessa he haastattelivat palveluiden käyttäjiä eli ihmisiä, jotka syystä tai toisesta olivat maahanmuuttajia eli "People on the Move" -otsakkeen alle kuuluvia. Kolmannessa vaiheessa kanssatutkijat haastattelivat niitä ammattilaisia, jotka työskentelivät maahanmuuttajien parissa. Ammattilaiset saivat käsiteltäväkseen haastattelussa myös yhteenvedon edellisestä vaiheesta eli maahanmuuttajien haastatteluista sekä mahdollisuuden reagoida tuloksiin. Tässä metodi tulee lähelle BIKVA-menetelmää, jossa seuraavan vaiheen haastatteluissa on mukana edellisessä vaiheessa koottu tieto (ks. lisää Krogstrup, 2004).

Laadin haastattelukysymykset sekä maahan/maasta muuttavien haastatteluihin että ammattilaisten haastatteluihin. Kun muuttajien haastattelukysymykset saivat kimmoketta maaraporteista, saivat ammattilaisten haastattelukysymykset kimmoketta muuttajien haastattelujen tuloksista. Halusimme mukaan erityyppisiä muuttajia, mutta valtaosa haastatelluista oli kuitenkin pakolaisia (turvapaikanhakijoita tai sisäisiä pakolaisia). 1Lisäksi haastatelluissa oli joitakin työn- ja opiskelun tai avioliiton perässä muuttaneita. 
Kuva muuttajista laajeni vielä ammattilaisten myötä, jotka toivat esille kohtaamiaan ihmisiä ja tilanteita. Ammattilaiset pohtivat auttamista myös laajemmin ja näin rakentui kuva ilmiöstä ja sen keskellä elävistä ihmisistä. Tutkimusraportti on luettavissa People on the Move - interdiac.

Kanssatutkijoiden osuus oli merkittävä, ilman heitä aineistoa ei olisi voitu kerätä. He käänsivät englanninkieliset haastattelukysymykset paikalliselle kielelle, tekivät sekä muuttajien että ammattilaisten haastattelut sekä lopulta käänsivät haastattelut vielä englanniksi. Kääntämisen työläydestä johtuen useimmat kanssatutkijat tyytyivät kääntämään vain yhteenvedon haastatteluista. Tämä saattoi vaikuttaa siihen, ettei kaikki tieto välittynyt minulle asti, koska kanssatutkijat suodattivat sen, mikä haastatteluissa oli tärkeää.

Tutkimusprosessin lopuksi järjestettiin yhteinen keskustelu tutkimuksen tuloksista. Keskustelussa jokainen kanssatutkija sai kommentoida tuloksia ja kertoa myös siitä, mikä näkökulma hänen mielestään vielä puuttui tai jäi vajaaksi. Näin tutkimuksen tulokset täydentyivät ja jäntevöityivät. Itse koin tämän keskustelun hyvin merkittävänä ja sillä oli tärkeä osa tutkimusraportin lopulliseen muotoon. Jos aloittaisin nyt tekemään uutta prosessia, järjestäisin yhteisiä online-tapaamisia muulloinkin kuin loppuvaiheessa. Myös haastattelukysymyksistä ja ohjeistuksista olisi voitu käydä yhteinen keskustelu. Näin meille olisi muotoutunut yhteinen näkemys, johon olisi voinut helpommin sitoutua.

Koronaviruspandemian osuminen keskelle ammattilaisten haastatteluvaihetta oli prosessia hidastuttava asia. Lopulta osa haastatteluista tehtiin internetin välityksellä. Myös Vuoristo- Karabahin aseellisella selkkauksella oli konkreettinen vaikutus erityisesti Armenian tilanteeseen, mutta kaikkien muidenkin osallisten mieliin. Kysymys ihmisistä liikkeessä tuli konkreettisesti iholle.

Kun tutkimusraportin raakaversio saatiin valmiiksi syksyllä 2020 kaikissa kolmessa tutkimusprosessissa, järjestettiin yhteinen työpaja-webinaari. Alkuperäinen tarkoitus oli tavata Serbiassa ja olla yhdessä muutama päivä tutkimusten äärellä. Nyt jouduimme tyytymään verkkoyhteyteen yhtenä päivänä.

Kaiken kaikkiaan kansainvälinen tutkimusprosessi oli opettava kokemus. Ensinnäkin pääsin kurkistamaan itäeurooppalaiseen ja keskiaasialaiseen maahanmuuttotilanteeseen. Toiseksi sain tutustua myös sitoutuneeseen uskontopohjaiseen työhön maahanmuuttajien parissa. Kolmanneksi opin paljon siitä, mitä on olla vastuussa prosessin tutkimuspuolesta. Ilman Oksana Prosvir- 
ninan sinnikkyyttä emme varmasti olisi saaneet tätä prosessia vedettyä läpi. Hänen yhteytensä paikallisiin kanssatutkijoihin oli merkittävää motivaation ja aikataulujen ylläpitämisen kannalta. Voisin lähteä samanlaiselle matkalle uudestaan.

\section{Lähteet}

Addy, T. (toim.) (2020). Ecclesiology and the Theology of Diaconian and Christian Social Practice - Case Study from Central and Eastern Europe and Central Asia. Ecclesiology and the Theology of Diaconia and Christian Social Practice - interdiac. Viitattu 23.3.2021.

Addy, T. \& Prosvirnina, O. (toim.) (2020a). People on the Move. Stories from churches and faith-based organisations in Central and Eastern Europe. People on the Move - interdiac. - Viitattu 23.3.2021.

Addy, T. \& Prosvirnina, O. (toim.) (2020b).
Voices of the young people in the "M". A Study of the Youth Diaconia in six Interdiac member organisations in Central and Eastern Europe and Central Asia. Voices of the young people in the "M" - interdiac. - Viitattu 23.3.2021.

Krogstrup, H. (2004). Asiakasläbtöinen arviointi. BIKVA-malli. https://www.julkari.fi/handle/10024/75625. - Viitattu 23.3.2021.

Sarajärvi, A. \& Tuomi, J. (2017). Laadullinen tutkimus ja sisällön analyysi. Uudistettu laitos. Tammi: Helsinki. 